\title{
Determinant Of Real Exchange Rate In Indonesia: Error Correction Model Approach
}

\author{
${ }^{1}$ Fradya Randa, ${ }^{2}$ Hasdi Aimon \\ 1Universitas Negeri Padang, Padang, Indonesia $\square$ fradya.randa@gmail.com \\ 2Universitas Negeri Padang, Padang, Indonesia $\bowtie$ s3dkpl@gmail.com
}

\begin{abstract}
The aim of this study is to examine the short-term and long-term relationship explain the shock of the real exchange rate in Indonesia. The analysis model is used cointegration of Johansen-juselius and error correction model (ECM). Data is used by time series from 1982 to 2017. The findings of this study found that trade openness, current account balance, and inflation significantly affected the real exchange rate. In the short term, inflation and foreign investment caused real exchange rate shocks in Indonesia directly. It is thus recommended amongst others that policies have to be put in place to stabilize the problem of inflation
\end{abstract}

Keywords: ECM, Cointegration, Rill Exchange Rate

\section{Introduction}

The exchange rate has a strong relationship with other economic fundamentals, both from the perspective of influence and policy. (Oriavwote \& Oyovwi, 2012) The real exchange rate occupies a central role of evaluation and design policy. Exchange rate of a country indicate its competitiveness in international economy and strengthen stability in a country (Raza \& Afshan, 2017). Therefore, appropriate efforts are needed to maintain exchange rate stability, so as not to endanger economic stability

The Indonesian government has involved for many years in international trade and has designed exchange rate policies to promote trade. Although exchange rate reform has been carried out by the government. However, the extent to which these policies have been effectived in promoting the economy in line with market expectations uncertainly. Figure 1 shows the exchange rate development of several real exchange rate systems that have been implemented in Indonesia. The global crisis in 1998 became the worst condition in the real exchange rate depreciation in Indonesia. External uncertainty and domestic economic fluctuations were the trigger factors for the drop of Rupiah exchange rate for the year.

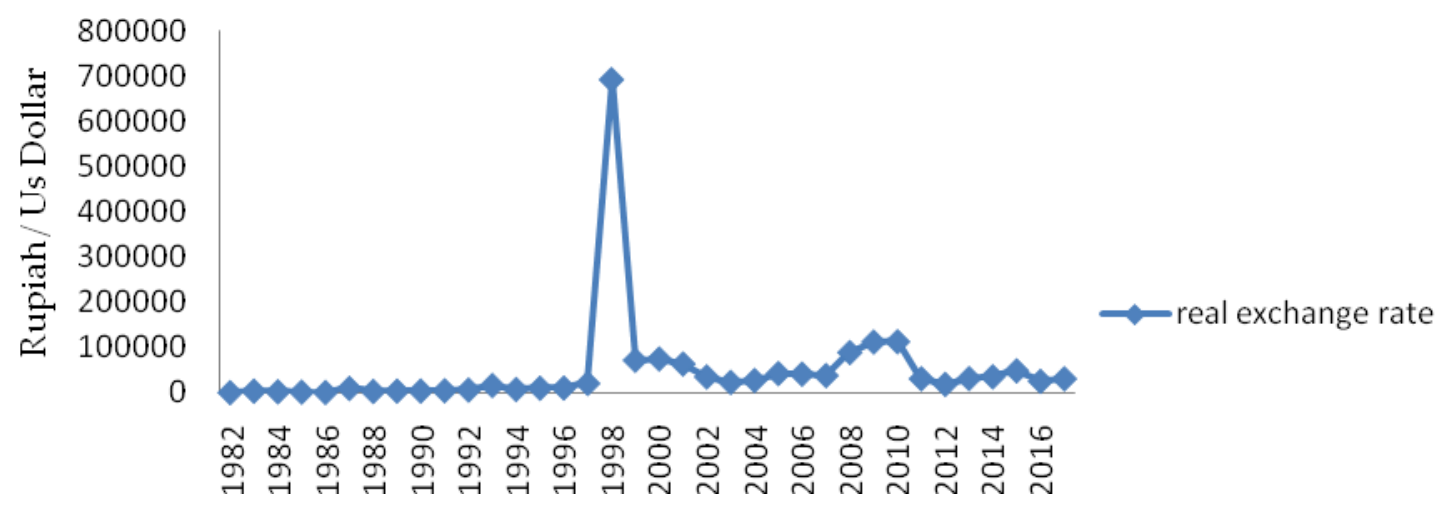

Figure 1 Real Exchange Rate

Source: World Bank (Authors' calculations)

The empirical study of (Carrera \& Restout, 2008) the real exchange rate volatility is influenced by the level of openness through the two main channels. First, theoretical influence, Trade liberalization 
reforms contribute to the depreciation of the long-term of real exchange rate. Policies such as reducing tariffs in increasing openness have caused a decline in domestic prices of imported goods. This condition will trigger an increase in excessive demand for imported goods and consequently, the real exchange rate depreciates to restore balance to the market. Second, openness to the market for goods and assets can play a role in facilitating and strengthening the impact of the real exchange rate. Research (Kilicarslan, 2018) supports the first channel, stating that an increase in openness will reduce the real exchange rate

Research (Adusei \& Gyapong, 2017; Gharaibeh, 2017) stated that improving the current account balance could weaken real exchange rates. The findings are supported by research (Saeed, Awan, Maqbool H . Sial, \& Sher, 2012; TSEN, 2014) the increase in the current account, in the long run, will affect the real exchange rate through demand and supply between countries.

Increased capital flows of foreign direct investment, provide additional sources of financing economic development and strengthen the real exchange rate (Hafeez-ur-Rehman, Jaffri, \& Ahmed, 2010). These findings are supported by research results (Alagidede \& Ibrahim, 2017; Jayasekara, 2017) increasing the foreign direct investment will lead to an appreciation of the real exchange rate. While research (Combes \& Kinda, 2011; Hussain, Berg, \& Aiyar, 2009) find different results, the flow of foreign direct investment does not affect the real exchange rate.

According to (Luqman \& Bashir, 2014) increasing the price of domestic goods will cause increasing demand for imported goods, thereby reducing the value of the domestic currency as a result of the depreciation of the real exchange rate. Research (Aye Khin, Yet Yee, Su Seng, Mei Wan, \& Qi Xian, 2017; Raza \& Afshan, 2017) also found that increasing inflation resulted in a depreciation of the real exchange rate.

Trade openness, current account balance, foreign direct investment (FDI) and inflation, are assumed to have an influence on real exchange rates in Indonesia. This research is intended to present a dynamic model of determining the real exchange rate and empirically examine the implications of changes in the possible determinants of short-term and long-term real exchange rate shocks in Indonesia. With the application of multivariate Johansen cointegration methods and error correction models (ECM).

Besides the introductory part, then the second part will discuss the methodology, the third part will analyze the results and discussion and the fourth part will conclude the conclusion.

\section{Methods}

The multivariate Johansen cointegration method and error correction model (ECM) is applied in the study. The data is used a time series from 1988 to 2017. The model of the long-term relationship of real exchange rates as follows:

$\mathrm{RER}=\mathrm{f}(\mathrm{TO}, \mathrm{CA}, \mathrm{FDI}, \mathrm{INF})$

Where RER (real exchange rate) is the nominal exchange rate (Rupiah against US Dollar) taking into account the price level between countries (Deflator GDP). Trade openness (TO) is the ratio of the number of exports and imports of GDP. The current account balance (CAD) is the ratio of exports minus imports to GDP. Foreign direct investment (FDI) is the ratio of foreign direct investment inflows to GDP. Inflation (INF) uses consumer price index data. The time series data is sourced from world development indicator, world bank. ER variable data in the form of logarithms while variable data (TO, CA, FDI, INF) are in the form of percentages so that they are not logged.

$$
\ln \mathrm{RER}_{\mathrm{t}}=\beta_{0}+\beta_{1} \mathrm{TO}_{\mathrm{t}}+\beta_{2} \mathrm{CA}+\beta_{\mathrm{t}} \mathrm{FDI}_{\mathrm{t}}+\beta_{4} \mathrm{INF}_{\mathrm{t}}+\varepsilon_{\mathrm{t}}
$$

Where $\varepsilon$ is a random error. The expected sign of the study is $\beta 1>0$ meaning the effect of trade openness on the real exchange rate has a positive coefficient, $\beta_{2}>0$ meaning that the effect of the current account balance on the real exchange rate is positively coefficient, $\beta_{3}<0$ meaning that the effect of foreign direct investment on the exchange rate has a negative coefficient, and $\beta_{4}>0$ meaning that the effect of inflation on the exchange rate has a positive coefficient. 


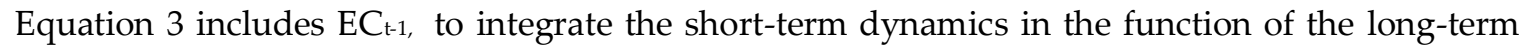
real exchange rate, so that the error correction model (ECM) is used as follows:

$\Delta \ln \mathrm{RER}_{\mathrm{t}}=\beta_{0}+\beta_{1} \Delta \mathrm{TO}_{\mathrm{t}}+\beta_{2} \Delta \mathrm{CA}_{\mathrm{t}}+\beta_{3} \Delta \mathrm{FDI}_{\mathrm{t}}+\beta_{4} \Delta \mathrm{INF}_{\mathrm{t}}+\mathrm{EC}_{\mathrm{t}-1+\mathrm{vt}}$

where $\mathrm{EC}_{\mathrm{t}-1}=$ error-correction term lagged one period.

Estimating of the study model involves three steps, namely: first, test unit root avoid false regression results. One of the unit root tests is used augmented dickey-fuller and Phillips-Perron. Second, the variables are integrated in the same order, then cointegration will be tested by using multivariate Johansen cointegration analysis. Third, the cointegrated variable, then we can determine the error correction model and the estimated standard method.

\section{Results and Discussion}

\section{Unit root test}

Unit root test is very important to do before conducting a cointegration test on the research variable. This test is intended to analyze the possibility of false regression which will show t-statistics and f-statistics that lead to wrong conclusions. So, time series data must be stationary or in the case of non-stationarity, the right methodology must be applied to correct. The study uses the augmented Dickey-Fuller (ADF) test for unit root tests.

Unit root test results in table 1 use augmented dickey-fuller, only RER and TO are stationary at the level, while other variables are nonstationary. Then continued testing on first difference, the results show stationary variables from the dickey-fuller augmented test.

Table 1 Unit root test Augmented dickey fuller

\begin{tabular}{cccccc}
\hline Variable & Level & Prob. Values & 1st difference & Prob. Values & \multirow{2}{*}{$\begin{array}{c}\text { Order of } \\
\text { integration }\end{array}$} \\
\cline { 2 - 4 } & \multicolumn{2}{c}{ Constant } & \multicolumn{2}{c}{ Constant } & \\
\hline RER & -5.358729 & 0.0001 & -9.577753 & 0.0000 & $\mathrm{I}(0)$ \\
TO & -3.231690 & 0.0264 & -9.042623 & 0.0000 & $\mathrm{I}(0)$ \\
CA & -2.380017 & 0.1544 & -6.154234 & 0.0000 & $\mathrm{I}(1)$ \\
FDI & -2.265869 & 0.1882 & -5.309581 & 0.0001 & $\mathrm{I}(1)$ \\
INF & 4.327728 & 1.0000 & -3.156538 & 0.0317 & $\mathrm{I}(1)$ \\
\hline
\end{tabular}

Notes: ADF test was performed using Eviews 8.0.

\section{Cointegration test}

The Johansen-Juselius cointegration test is applied to find out the equilibrium in the long run. Are there similarities in the movement and stability of the relationship between the variables in this study or not.

Table 2 Johansen-Juselius multivariate cointegration test

\begin{tabular}{ccccccc}
\hline H0 & H1 & Eigenvalue & $\begin{array}{c}\text { Trace } \\
\text { Statistic }\end{array}$ & $\begin{array}{c}\mathbf{0 . 0 5} \\
\text { Critical Value }\end{array}$ & $\begin{array}{r}\text { Max-Eigen } \\
\text { Statistic }\end{array}$ & $\begin{array}{c}\mathbf{0 . 0 5} \\
\text { Critical Value }\end{array}$ \\
\hline $\mathrm{r}=0$ & $\mathrm{r}>0$ & & & & & \\
& & 0.775988 & 90.11662 & 69.81889 & 49.36977 & 33.87687 \\
$\mathrm{r} \leq 1$ & $\mathrm{r}>1$ & 0.418321 & 40.74685 & 47.85613 & 17.88059 & 27.58434 \\
$\mathrm{r} \leq 2$ & $\mathrm{r}>2$ & 0.305663 & 22.86626 & 29.79707 & 12.03835 & 21.13162 \\
$\mathrm{r} \leq 3$ & $\mathrm{r}>3$ & 0.239958 & 10.82791 & 15.49471 & 9.054598 & 14.26460 \\
$\mathrm{r} \leq 4$ & $\mathrm{r}>4$ & 0.052318 & 1.773314 & 3.841466 & 1.773314 & 3.841466 \\
\hline
\end{tabular}

Notes: ${ }^{*}$ denotes rejection of the hypothesis at the 0.05 level. these nonstandard critical values are taken from MacKinnon-Haug-Michelis (1999)

Akaike information criterion (AIC) and Schwarz information criterion (SC) from the VAR estimation, inform that the optimal lag length is used 2. In table 3 states that the trace statistic value of 90.11662 is above the critical value of 69.81889 at $r=0$, it means that the hypothesis of no cointegration 
is rejected, and the alternative hypothesis is accepted. The max-eigen statistic value is greater than the value of critical value, meaning the null hypothesis of no cointegration at $r=0$ rejected at a 0.5 percent significant level, and supports the alternative hypothesis.

It can be summed up there is a cointegration relationship on the variables studied. The cointegration relationship states that there is a long-term balance between exogenous and endogenous variables in this study.

Table 3 estimation of Ordinary Least Square (OLS)

\begin{tabular}{|c|c|c|c|c|}
\hline Variable & Coefficient & Std. Error & t-Statistic & Prob. \\
\hline $\mathrm{C}$ & $5.488640^{*}$ & 0.696085 & 7.885017 & 0.0000 \\
\hline TO & $0.068330^{*}$ & 0.012236 & 5.584523 & 0.0000 \\
\hline CA & $0.188621^{*}$ & 0.045722 & 4.125377 & 0.0003 \\
\hline FDI & 0.161081 & 0.096151 & 1.675291 & 0.1039 \\
\hline INF & $0.015941^{*}$ & 0.002670 & 5.969491 & 0.0000 \\
\hline R-squared & 0.869173 & F-statistic & 51.48854 & \\
\hline $\begin{array}{l}\text { Adjusted R- } \\
\text { squared }\end{array}$ & 0.852292 & $\begin{array}{l}\text { Prob(F- } \\
\text { statistic) }\end{array}$ & 0.000000 & \\
\hline
\end{tabular}

Estimated Ordinary Least Square (OLS) table 3 shows the openness of trade (TO), the current account balance (CA) and inflation (INF) significantly influence the real exchange rate the long-term in Indonesia. Increased trade openness has an impact on the real depreciation of the exchange rate in Indonesia. 1 percent increase in trade openness, in the long-term, will weaken the real exchange rate by 0.06 percent. Increasing the current account balance will weaken the real exchange rate in Indonesia.

Furthermore, increasing the inflation, in the long run, causes a real depreciation of the exchange rate in Indonesia. However, foreign direct investment in the long term does not have a significant effect on the real exchange rate in Indonesia. The finding supports the results of previous studies (Combes \& Kinda, 2011; Hussain et al., 2009) that there is no relationship between foreign direct investment and exchange rates.

\section{Estimation of the error correction model}

The stability of the parameters study model in the long term can be checked by the error correction model (ECM). So that, it can be known the variables that affect the real exchange rate in the short term and the variables that cause a real exchange rate shock.

Table 4 Estimasi error- correction model

\begin{tabular}{|c|c|c|c|c|}
\hline Variable & Coefficient & Std. Error & t-Statistic & Prob. \\
\hline C & 0.066894 & 0.141247 & 0.473592 & 0.6393 \\
\hline $\mathrm{D}(\mathrm{TO})$ & 0.069058 & 0.009125 & 7.568399 & 0.0000 \\
\hline $\mathrm{D}(\mathrm{CA})$ & 0.184868 & 0.054223 & 3.409404 & 0.0019 \\
\hline $\mathrm{D}(\mathrm{FDI})$ & 0.040992 & 0.103645 & 0.395506 & 0.6954 \\
\hline $\mathrm{D}$ (INF) & 0.006952 & 0.029053 & 0.239289 & 0.8126 \\
\hline RES(-1) & -0.787630 & 0.181284 & -4.344726 & 0.0002 \\
\hline R-squared & 0.764618 & F-statistic & 18.84079 & \\
\hline $\begin{array}{l}\text { Adjusted R- } \\
\text { squared }\end{array}$ & 0.724035 & Prob(F-statistic) & 0.000000 & \\
\hline
\end{tabular}

The next discussion is about the short-term relationship between trade openness, the current account balance, direct foreign investment and inflation in Indonesia. So it is known, the model of the real exchange rate equilibrium that is in line with market expectations, and does not disturb economic 
stability. This condition can be seen in the results of the ECM estimation of the real exchange rate in table 4.

The estimation results show that the error term lag significantly affects the shock of the real exchange rate. This shows that there is an imbalance in the short-term relationship between changes in the flow of foreign direct investment and inflation with the real exchange rate. Foreign direct investment and inflation have no significant effect on the real exchange rate. It means that the cause of the real exchange rate shock is the flow of foreign direct investment and inflation.

However, in the short term, trade openness and the current account balance have a significant effect on the real exchange rate in Indonesia. The condition means that in the short term control of the flow of foreign direct investment and the current account balance is needed the real exchange rate to the level needed by the market expectation equilibrium.

$\mathrm{R}^{2}$ determinant coefficient value is quite high, 76 percent of the total variation of the real exchange rate in Indonesia, can be explained by the macroeconomic variables studied. While Error correction term illustrates the proportion of the imbalance of the real exchange rate, in the long-term, can be corrected annually at a significant level of 1 percent. It is around 78 percent of the imbalances in the real exchange rate shock is being corrected every year in Indonesia.

\section{Conclusion}

The central role of the exchange rate in the evaluation and design of economic policies cannot be separated from the Indonesian economy. Therefore, efforts need to be made place the position of the exchange rate in a position that is in line with the balance needs of market expectations. There are many real linkages between exchange rates and other economic fundamentals. Based on the results of the cointegration and ECM tests performed. Foreign direct investment and inflation in the short term cause real exchange rate shocks in Indonesia. Therefore, it needs to be a concern for policy makers, to take appropriate policy to maintain the balance of the real exchange rate.

\section{References}

Adusei, M., \& Gyapong, E. Y. (2017). The impact of macroeconomic variables on exchange rate volatility in Ghana: The Partial Least Squares Structural Equation Modelling approach. Research in International Business and Finance, 42, 1428-1444. https://doi.org/10.1016/j.ribaf.2017.07.081

Alagidede, P., \& Ibrahim, M. (2017). On the Causes and Effects of Exchange Rate Volatility on Economic Growth: Evidence from Ghana. Journal of African Business, 18(2), 169-193. https://doi.org/10.1080/15228916.2017.1247330

Aye Khin, A., Yet Yee, C., Su Seng, L., Mei Wan, C., \& Qi Xian, G. (2017). Exchange Rate Volatility on Macroeconomic Determinants in Malaysia: Vector Error Correction Method (Vecm) Model. Journal of Global Business and Social Entrepreneurship (GBSE), 3(5), 36-45. Retrieved from http://gbse.com.my/v3no5may17/Paper-78-i-.pdf

Carrera, J. E., \& Restout, R. (2008). Long Run Determinants of Real Exchange Rates in Latin America. Centre National de La Recherche Scientifique, W.P.08-11. https://doi.org/10.2139/ssrn.1127121

Combes, J., \& Kinda, T. (2011). Capital Flows , Exchange Rate Flexibility , and the Real Exchange Rate. IMF Working Paper.

Gharaibeh, A. M. O. (2017). Fundamental determinants of real effective exchange rate: Empirical evidence from Bahrain. International Journal of Economic Research, 14(13), 251-267.

Hafeez-ur-Rehman, Jaffri, A. A., \& Ahmed, I. (2010). Impact of Foreign Direct Investment (FDI) Inflows on Equilibrium Real Exchange Rate of Pakistan. South Asian Studies (1026-678X), 25(1), 125-141. Retrieved from http://search.ebscohost.com/login.aspx?direct=true\&db=a2h\&AN=65566406\&site=ehost-live

Hussain, M., Berg, A., \& Aiyar, S. (2009). The macroeconomic management of increased aid: Policy lessons from recent experience. Review of Development Economics, 13(3 SPEC. ISS.), 491-509. https://doi.org/10.1111/j.1467-9361.2009.00503.x 
Jayasekara, S. G. S. D. (2017). Exchange Rate Volatility and Foreign Direct Investment in Sri Lanka. International Journal of Economics , 9 ( 1 ), 1-14, 9, 1-14. Retrieved from https://www.researchgate.net/publication/303881056\%0AJayasekara

Kilicarslan, Z. (2018). Determinants of exchange rate volatility: empirical evidence for Turkey. Pressacademia, 5(2), 204-213. https://doi.org/10.17261/pressacademia.2018.825

Luqman, A., \& Bashir, F. (2014). Long run Determinants of Real Exchange Rate: An Econometric Analysis from Pakistan. Pakistan Journal of Commerce and Social Sciences, Vol. 8(2), 471-484. Retrieved from https://www.researchgate.net/publication/309556171\%0ALong

Oriavwote, V. E., \& Oyovwi, D. O. (2012). The Determinants of Real Exchange Rate in Nigeria. International Journal of Economics and Finance, 4(8). https://doi.org/10.5539/ijef.v4n8p150

Raza, S. A., \& Afshan, S. (2017). Determinants of Exchange Rate in Pakistan: Revisited with Structural Break Testing. Global Business Review, 18(4), 825-848. https://doi.org/10.1177/0972150917692210

Saeed, A., Awan, R. U., Maqbool H . Sial, \& Sher, F. (2012). An econometric analysis of determinants of exchange rate in Pakistan. International Journal of Business and Social Sceinces, 3(6), 184-196.

TSEN, W. H. (2014). the Real Exchange Rate Determination: Empirical Evidence From Malaysia. The Singapore Economic Review, 59(2), 1450016. https://doi.org/10.1142/s0217590814500167 